Pace University

DigitalCommons@Pace

\title{
Keeping It Legal: Transboundary Management Challenges Facing Brazil and the Guarani
}

David N. Cassuto

Elisabeth Haub School of Law at Pace University

Follow this and additional works at: https://digitalcommons.pace.edu/lawfaculty

Part of the Comparative and Foreign Law Commons, Environmental Law Commons, International Law Commons, and the Water Law Commons

\section{Recommended Citation}

David N. Cassuto \& Romulo S.R. Sampaio, Keeping It Legal: Transboundary Management Challenges

Facing Brazil and the Guarani, 36 Water Int'I 661 (2011), http://digitalcommons.pace.edu/lawfaculty/792/.

This Article is brought to you for free and open access by the School of Law at DigitalCommons@Pace. It has been accepted for inclusion in Pace Law Faculty Publications by an authorized administrator of DigitalCommons@Pace. For more information, please contact dheller2@law.pace.edu. 


\title{
Keeping it legal: transboundary management challenges facing Brazil and the Guarani
}

\author{
David N. Cassuto ${ }^{a}$ and Romulo S.R. Sampaio ${ }^{\mathrm{b} *}$ \\ ${ }^{a}$ Pace Law School and Brazil-American Institute for Law \& Environment (BAILE), White Plains, \\ New York, USA, ${ }^{b}$ Research Program on Law \& the Environment, FGV Law School, Rio de Janeiro, \\ Brazil and Brazil-American Institute for Law \& Environment (BAILE), White Plains, New York, USA
}

\begin{abstract}
This paper examines the legal and ecological problems facing the Guarani Aquifer System. Because the majority of the Guarani Aquifer System underlies Brazil, the Brazilian legal regime forms the paper's principal focus. The importance of the region makes the need for accurate information crucial. Yet relying on such information to manage a complex resource presents risks. Too often, the role of uncertainty in regulating is underplayed. Increasing knowledge over the resource demands categorizing "hard" and "soft" uncertainties, especially those presented by climate change. In addition, regulators must acknowledge the unitary nature of the aquifer while remaining sensitive to differing national priorities.
\end{abstract}

Keywords: Guarani; uncertainty; climate change; Acordo; Brazil; transboundary

\section{Overview of regional ecology}

The Guarani Aquifer System (GAS) underlies Brazil, Paraguay, Uruguay and Argentina. The GAS is the world's largest aquifer. It was first discovered in 1996 and was named for the indigenous people who have inhabited the region for centuries (Brzezinski 2010). The aquifer contains $30,000 \mathrm{~km}^{3}$ of water, 1.2 million $\mathrm{km}^{2}$ of surface area and comprises one of the most important eco-regions in the world (Almanaque Brasil Socioambiental 2008). It is integrally connected through overland rivers (the Parana and the Paraguay) with the Pantanal, the largest wetland in the world, which oversits Bolivia, Paraguay and Brazil (Almanaque Brasil Socioambiental 2008). The GAS recharge zones are primarily located in Brazil and in Paraguay whilst the discharge zones reside in Argentina and Uruguay (Usunoff n.d.). The annual recharge rate is estimated at 45 to $55 \mathrm{~km}^{3}$ of water, which represents less than $0.2 \%$ of the freshwater storage (Schmidt and Larroza 2010). The health of the Guarani and the issues created by that transboundary overlap present a complex management dilemma arising from, among other things, the absence of precise technical and scientific information related to underground water.

Annual extraction levels of the GAS currently hover around $1.04 \mathrm{~km}^{3} /$ year - well within recharge levels of the aquifer as a whole, and approximately $.003 \%$ of the total (World Bank 2009). At current levels of exploitation, the Guarani Aquifer could offer the four overlying nations fresh water for over 2,000 years (Amore and Tröger 2010). ${ }^{1}$ Although impressive at first glance, this statistic should not undermine the importance

\footnotetext{
*Corresponding authors. Emails: dcassuto@law.pace.edu; romulo.sampaio@fgv.br
} 
of integrated management policies among the four overlying nations, especially in light of the exponential increase in pressure on groundwater resources worldwide. Economics plays a significant role in determining how the Guarani will be utilized. Since at present there are significant alternative surface-water sources, it is generally not cost-effective to extract water from the aquifer for irrigation or other heavily consumptive uses. However, as climate change shifts the amount and availability of other water, the economics could change. $^{2}$

Use of the GAS waters varies by region, with the majority going to public water supply, but significant amounts also going toward agricultural and industrial uses and recreation (primarily thermal tourism) (Amore and Tröger 2010). ${ }^{3}$ Brazil relies most heavily on the Guarani, extracting $87 \%$ of the total water withdrawn (Amore and Tröger 2010). This is due both to the country's size and demographics, as well as the fact that it overlies the majority of the aquifer. The state of São Paulo exerts the greatest pressure (Schmidt and Larroza 2010). ${ }^{4}$ The regional ecology as well as socioeconomic complexity present an array of managerial challenges. The transboundary nature of the Guarani Aquifer further complicates management.

\section{Brazilian laws and policies regarding the Guarani Aquifer}

We focus here on Brazilian laws and policies regarding the GAS for several reasons. First, Brazilian management practices potentially have the greatest impact on the implementation of the recently signed (but not yet ratified) agreement, the Acordo 2010, which acknowledges the authority of each overlying nation to manage that portion of the aquifer over which it sits. Brazil's actions will have the largest impact on the aquifer's heath and resilience. Its responsibility to implement sound water-management practices is therefore the greatest.

Second, the variety of Brazil's activities on the overlying land requires different and yet integrated management strategies. For example, even within a single activity like agribusiness, water needs and impacts can vary. Intense crop use can lead to considerable drawdown, whereas industrial livestock production in another region might lead to groundwater contamination. The Guarani is thus vulnerable to a wide range of activities and policies some of which, such as land use, do not even necessarily implicate the aquifer directly (Almanaque Brasil Socioambiental 2008). In Brazil, municipalities enjoy considerable legal and managerial authority over zoning, posing their own set of challenges for groundwater management.

Third, from a practical perspective, the background and expertise of the authors permits us far more insight into the international and Brazilian legal framework for transboundary and groundwater management. Nonetheless, we acknowledge that a truly comprehensive analysis of the Guarani must include a similar treatment of Paraguay, Uruguay and Argentina.

\section{The legal and regulatory framework}

Historically, Brazilian legislators have paid very little attention to groundwater (Benjamin et al. 2005). Consequently, the legal regime dealing with groundwater issues in Brazil is of comparatively recent vintage. Growing pressure over this scarce resource is forcing policymakers to address the regulatory gap between surface water and groundwater. The challenge has been to integrate surface and groundwater management (Benjamin et al. 2005). 
A new paradigm in water law was established in Brazil by the 1988 Federal Constitution and the 1997 National Water Policy Act (Brazilian National Water Management Policy Act 1997). Prior to 1988, private ownership over water resources was permissible (Pompeu 2006). The 1988 Constitution introduced the notion that the environment is an asset of common use and essential to a healthy quality of life. This principle covers water as well (Freitas 2002). No one owns water and all people shall have equal and unfettered access to it. ${ }^{5}$ Codifying statutes on the nature of water as a public good soon followed. For example, Article 99 of the 2002 Brazilian Civil Code states that rivers and oceans are public assets of common use and Article 1 of the National Water Policy Act declares that water lies within the public domain (Brazilian Civil Code 2002). ${ }^{6}$ This constitutional and statutory combination places water firmly within the legal category of public assets of common use.

However, the aforementioned shift focused primarily on surface water. The issue of groundwater in the 1988 Constitution was limited to jurisdictional issues regarding the managerial powers of the federal and state governments. Article 20, section III, of the 1988 Constitution entrusts the federal government with managing lakes, rivers and watercourses on lands within its domain, that wash more than one state and that serve as boundaries with other countries (Constituição da República Federativa do Brasil 1988, atr. 20, § III). It also extended jurisdiction over beaches and the territorial sea (Constituição da República Federativa do Brasil 1988, atr. 20, § III). By contrast, Article 26 entrusts States with managing groundwater (Constituição da República Federativa do Brasil 1988, atr. 26). This bifurcated authority creates a serious management problem for aquifers such as the Guarani that underlie multiple states and extend beyond national jurisdiction.

Entrusting individual states with differing priorities and management strategies to manage a resource of multilateral and international significance creates federalist tension and jeopardizes international bilateral agreements. To solve this problem, judges and scholars maintain that the concept of watercourses in Article 20 should be broadly construed to include groundwater that serves as boundaries with other countries and/or wash more than one state (Constituição da República Federativa do Brasil 1988, atr. 20). However, this interpretation is not yet settled and seems to flout the plain language of the Constitution. A constitutional amendment has been proposed to address this issue, but has not yet been ratified by the Congress.

Meanwhile, a set of different regulations has been enacted to close the gap between the groundwater and surface water management regimes. The need for integration has become particularly urgent as a result of ballooning demand for water by agribusiness. In 2001, the National Water Resources Council (CNRH) enacted a series of resolutions aimed at integrating ground and surface-water management (Benjamin et al. 2005). In addition, the National Environmental Council (CONAMA) also promulgated groundwater quality standards in 2008 (Sant'Anna 2002).

Those states overlying the Guarani have also taken steps to control access and promote conservation. For instance, the state of São Paulo, the main consumer of water from the Guarani Aquifer, created the State Water Resources Council (CERH-SP) to regulate to protect the State's water resources. It established restricted zones for the perforation of tubular wells in the city of Ribeirão Preto, one of the major consumers within São Paulo, in order to shield the Guarani from contamination. This regulation was approved based on the conclusions of a report produced by the Companhia Ambiental do Estado de São Paulo (CETESB). Another example of a brewing conflict lies in the state of Mato Grosso do Sul, where the passage of Resolution 8 in July 2009 empowers the state Environmental Authority to require permits for property owners seeking to operate wells on their land. 
However, as the agency begins rationing permits to prevent groundwater overdraft, property owners whose title predates the 1988 Constitution could potentially file takings claims.

Other policies with the potential to impact indirectly the management and use of waters within the GAS include those related to land use. In addition to the already troublesome jurisdictional problem over groundwater resources, power over land use policies are shared by the federal, state and municipal governments with emphasis on the latter. Article 30, I and II, of the Brazilian Constitution empowers municipalities to legislate over matters of local impact (Constituição da República Federativa do Brasil 1988, atr. 30, §§I-II). The above-stated example of the city of Ribeirao Preto is one such example. Land-use policies must take into account the potential negative impacts on overall management policies for the conservation and sustainable use of the GAS.

\section{Regulating the Guarani Aquifer System}

The international legal framework on groundwater is constantly evolving. In general, international laws regarding groundwater build on rules already in place for surface water. Of particular relevance to the Guarani is the 1966 Helsinki Rules on the Uses of the Waters of International Rivers, which was adopted by the International Law Association (ILA) and laid out foundational principles for transboundary water issues (Benjamin et al. 2005). This agreement was followed by the 1997 UN Convention on Non-Navigational Uses of Watercourses which led to the 2004 Berlin Rules on Water Resources.

The international legal framework for groundwater also encompasses the 1986 Seoul Rules on International Groundwaters, and the 1994 UN International Law Commission Resolution on Confined Transboundary Groundwater. Further, in 2008 the United Nations General Assembly (UNGA) suggested to member states that they consider adopting the draft articles contained in the Resolution (UNGA Resolution 63/124) (UNGA 2011).

International agreements specifically dealing with the Guarani Aquifer include the 1969 Treaty on the La Plata Basin (Benjamin et al. 2005). This treaty provides the foundation upon which the Guarani Aquifer Environmental Protection and Sustainable Development Project was construed. All the aforementioned multilateral agreements laid the foundation for the Acordo 2010. The overlying nations signed the Acordo on 2 August 2010. It will enter into force 30 days after it has been ratified in all four countries. The ratification procedure varies significantly from country to country and may take several years to complete.

\section{Agreement on the Guarani Aquifer (Acordo 2010)}

The Acordo 2010 outlines basic principles adopted by all the signatory countries and will represent a step forward for the aquifer's management while still respecting domestic autonomy if ratified by the four nations. However, Article 2 does oblige the signatories to manage the aquifer in accordance with governing principles of international law (Acordo sobre o Aquífero Guarani 2010). This includes the obligation, enumerated in Article 3, to not cause harm to another party or to the environment (Acordo sobre o Acquifero Guarani 2010). It also imposes multilateral obligations which include protecting and conserving the aquifer in a manner assuring multiple, rational, sustainable and equitable uses (Acordo sobre o Aquífero Guarani, Art. 4 2010). ${ }^{7}$

The Acordo will also represent a significant achievement in the field of international water law. To date, only a handful of international groundwater-management agreements exist despite the existence of at least 270 transboundary aquifers, which provide water to millions of people (Benjamin et al. 2005). 
The agreement adopts a number of important management principles. For example, the four nations agree to share information as well as to inform their fellow signatories of any domestic initiatives that may cause transboundary impact. Furthermore, Article 4 of the agreement acknowledges the multilateral importance of protecting and conserving the aquifer as well as the need to identify areas requiring special attention, especially those near the borders (Acordo sobre o Aquífero Guarani 2010). However, as is often the case in multiparty agreements, the language is broad and may simply be papering over disputed issues (Benjamin et al. 2005). Similarly, Article 15, which creates a multilateral commission to oversee and manage cooperation between the parties, does not set out any specific duties or authority of the Commission. Instead, it simply states that the Commission will propound its operating regulations at a later date. This leaves the nascent Commission without a clear mandate.

Concerns over the nature and scope of the sovereignty guaranteed to the signatory nations in Article 2 are already the subject of vigorous debates (McCaffrey and McIntyre 2010). For instance, some would argue that the fact that such language could find itself into a transboundary water agreement in 2010 reflects the enormous difficulty that continues to bedevil international ground and surface-water management (Eckstein 2010). This debate over the extent and understanding of what sovereignty means is unlikely to be resolved any time soon. In the interim, a more practical solution would be to recognize that states can and must collaborate based on a shared vision of existing principles of domestic and international environmental laws.

Because the Guarani - like all transboundary water resources - falls under multiple national jurisdictions and because the policies of the respective nations toward overdraft and pollution may impact the rest of the aquifer, the management strategies of the four countries must be harmonized in order to function effectively. That strategy can derive from principles of reasonable and equitable use (Acordo sobre o Aquífero Guarani 2010, Art. 3, 4) as well as principles of no significant harm (Acordo sobre o Aquífero Guarani 2010, Art. 3, 6, 7). Even as the Acordo recognizes these key precepts, its enforcement mechanisms remain underdeveloped. This lack of a shared approach to enforcement is understandable in light of the different national interests involved. However, its absence could hinder future efforts to manage the resource multilaterally. For example, the Commission that it creates lacks any enforcement power. The parties are merely required to "consult" with the Commission but its recommendations are not binding. (Acordo sobre o Aquífero Guarani 2010, Art. 17). In addition, the Acordo's arbitration clause does not bestow any power or authority not already present in international law (Acordo sobre o Aquífero Guarani 2010, Art. 19). Given the looming challenges of climate change, that reality becomes especially sobering (Hall et al. 2008).

Harmonizing domestic policies and building efficient commonly shared management strategies requires a thorough understanding of the four national water-regulatory systems. However, a preliminary and equally important task involves acknowledging the challenges posed by the complexity of each domestic legal groundwater regime. The Acordo offers a broad set of policy objectives. Those objectives only become possible if they do not run afoul of the countries' respective groundwater legal regimes. Consequently, the success of the Acordo depends on the ability of the four countries to harmonize their respective approaches to groundwater management - at least with respect to the Guarani. Opining on the scope of all four countries' legal regimes lies outside the scope of this article. We rather intend to offer some insights into the challenges existing within the Brazilian legal framework, because we believe it crucial that such a framework exist before Brazil can participate effectively in a common and harmonized multilateral regulatory strategy. 


\section{Hydrological challenges presented by climate change}

\section{The Brazilian legal approach}

Climate change presents significant challenges relating to water availability. The situation in Brazil is serious and rapidly worsening. Long periods of drought are becoming more frequent, even in wet states in the south, like Paraná and Rio Grande do Sul. A major diversion project aimed at diverting water from the San Francisco River for the arid northeast region of Brazil offers another example of how water management policies in a country known for its water abundance must now focus on avoiding water shortages.

According to the Intergovernmental Panel on Climate Change (IPCC), there is "high confidence" that northeastern Brazil "will suffer a decrease in water resources due to climate change" (IPCC 2007). The report projects significant adverse impacts on agriculture, water supply, energy production and health. While dry regions will become drier, there will also be changes in rainfall patterns and runoff in traditionally humid zones. This will impact water availability and water quality, and will present challenges to infrastructure (Hall et al. 2008).

Brazil implemented a national climate-change policy at the end of 2009 that highlights the need to manage natural resources in light of the risks posed by climate change. However, the policy offers guidelines rather than any specific plan of action. Specific regulatory measures were left to the executive branch to enact and also delegated to states and municipalities. In 2010, the first step on regulating the National Climate Change Policy Act (NCCPA) was conceived. Decree n. 7,390 of 9 December 2010 was then enacted with the purpose of regulating the NCCPA. While the Decree provides more specific guidance on the implementation aspects of NCCPA, it is still quite broad and lacks concrete enforceable rules (Presidency of the Republic Casa Civil Cabinet Subcommittee for Legal Affairs 2010).

Incorporating the guidelines of the new climate-change policy act and regulations into existing water law will present significant challenges. The principles embedded in the 1997 National Water Policy Act demonstrate an emerging awareness that water management must adapt to modern environmental realities, including climate change (Hall et al.2008). Together with the 2009 National Climate Change Policy Act, principles such as the precautionary approach, intergenerational equity, multiple use and risk assessment now infuse the Brazilian water regime. However, enforcement remains a significant issue for Brazil as well as the other three countries (McAllister 2008).

The Acordo is similarly ill equipped for the challenges of climate change. It contains no reference to climate change nor to existing international climate change law. Given the inevitable impact of climate change on water availability and quality - even on a resource as vast as the GAS - that lack seems short-sighted.

The task now facing the nation involves fashioning an independent regulatory apparatus that can withstand campaigns to manipulate public opinion and undermine sound policy making. Sound water policy making in the post-climate-change world requires acknowledging the principles and guidelines already in place despite the pressures created by large-scale development projects that fail to account for the new water-scarce reality.

\section{Transboundary challenges}

The recent evolution of international laws and agreements regarding the Guarani Aquifer offers a first step toward a successful management regime (Benjamin et al. 2005). International cooperation enabled the involved countries to assess the challenges imposed 
by the many ecosystemic and political variables. Those variables range from the threat of climate change to significant and potentially irreversible impacts on different ecosystems including the Pantanal (Hall et al. 2008). Inventorying uncertainties is a necessary first step to provide for the needs of the overlying countries (Sunstein 2004). It is also a precondition for a second important initiative: reducing asymmetric information. That, in turn, requires qualified public participation at all levels of policy making.

Development pressures and conservation goals offer fertile ground for conflicting interests within the overlying countries. These conflicts can lead to a tragedy of the commons if not properly managed. On the other hand, overregulation can cause sub-optimal use, thereby impairing development. Optimizing regulation presents an ongoing challenge but the obstacles grow larger when the commons is as complex as the Guarani Aquifer. The complexity and environmental importance of the region, as well as the looming threats presented by climate change, make the need for accurate and detailed scientific and technical information urgent and crucial (Hall et al. 2008). Yet relying on such information to manage such a complex natural resource also presents risks (Beck 1986).

Environmental uncertainty can never be eliminated; at best it can be quantified and certain aspects of it reduced (Schroeder 1986). Too often, however, the role of uncertainty in risk assessment and in legal and managerial decisions gets reduced or ignored (Wildavsky 1966). Understanding the role of uncertainty and how to best manage it is necessary to achieve a stable regulatory framework - not just for the Guarani region, but for all transboundary water regimes.

Decreasing uncertainty requires reducing asymmetric information. In other words, policy makers must bridge the gaps among scientists coming from different areas of knowledge as a first attempt to mitigate the impacts of the socio-economic burdens borne by the regulated sectors (Krier 1990). Local and traditional knowledge, particularly for a resource as vast as the Guarani, must also be taken into consideration. Capacity building is crucial. Users must have access to state-of-the-art scientific information couched in language that is accessible to non-specialists. The less asymmetric information, the lower the degree of uncertainty and, consequently, the more likely regulatory decision will be beneficial (Rowe and Frewer 2004). In this context, beneficial means both more legitimate and more procedurally efficient, taking into account the competing uses and needs of different regions within Brazil and within the four overlying nations (Laffont 2000).

With regard to the Guarani, recent developments reveal a laudable collaboration aimed at reducing asymmetric information at all levels: international, regional and local. However, public participation must also play a key role. Vital pieces of the puzzle sometimes are only provided by traditional and local knowledge (Benjamin et al. 2005). Another crucial component of a successful multilateral management strategy (and here we refer both to multi-state as well as multinational resource management) lies with coordinating actions and plans. Shared information is an often-overlooked management tool.

Underlying the need for comprehensive information sharing on the Guarani is the need to determine whether management strategies face challenges predicated on hard or soft uncertainty. Soft uncertainty arises "where [a] precise outcome cannot be predicted but a probability distribution can be specified ..." (Wildavsky 1966). Hard uncertainty occurs "where one does not even know the parameters of the outcomes" (Wildavsky 1966). Identifying which policies fall under which category is crucial.

For example, development issues present a soft uncertainty challenge. Potential threats are, for the most part, knowable and their potential impacts are calculable. Climate change impacts, by contrast, present a problem of hard uncertainty (Posner and Sunstein 2008). The dimensions of the threat are not yet measurable and the impacts remain mostly 
unknown. In other words, threats posed by development present a known unknown while climate change presents multiple challenges predicated on unknown unknowns.

For the former, local policies organized and coordinated by a common set of principles that acknowledge the transboundary nature of the resource might be most efficient. As mentioned, the recent multilateral agreement exemplifies both the advantages and drawbacks to this approach. For the threats posed by climate change, strategies and policies built at the local level must acknowledge the hard uncertainty underlying the global problem. No local strategy can possibly address the complexity of the dilemma, nor should it. However, local strategies that do not account for global challenges and strategies are doomed to fail. Understanding this reality is particularly important in the case of landuse policies designed and developed under the municipal powers granted by the Brazilian Constitution.

The policy challenges at both the local and international levels will require attention to the precautionary approach, which includes understanding and managing for the catastrophic potential of low-probability events. This involves constructing mitigation policies that navigate dangers presented by unknown and unpredictable events while remaining non-exclusionary and not unduly burdening regulated sectors (Schelling 1992). This task seems impossible. Yet it must be done. The Guarani - and much more - hang in the balance.

\section{Conclusion}

In sum, the legal framework for the Guarani represents progress but also highlights the challenges and risks ahead. Brazil's constitutional predicament with respect to transboundary groundwater, as well as other domestic legal hurdles, further complicates an already difficult multilateral management process. Overcoming these challenges and effectively managing the Guarani will require both domestic legal reform as well as increased attention to hard and soft uncertainty questions. Once categorized, policy makers must allow for public participation through the promotion of awareness, capacity building, community involvement and traditional knowledge. In addition, the regulatory framework must acknowledge the unitary nature of the aquifer while still remaining sensitive to differing national and local priorities. This challenge - faced by every transnational water negotiation - looms particularly large with the Guarani because of the size and importance of the resource, and because of its impact on other sensitive and protected regions.

\section{Acknowledgements}

The authors would like to acknowledge gratefully the invaluable research work provided by Carolina Gueiros, Brazilian attorney and LL.M. Candidate at Pace Law School, as well as by Shaina Brenner, Stephen Iannacone and Joseph Edgar, J.D. candidates at Pace Law School.

\section{Notes}

1. "The static water reserves were calculated as higher than $29,551 \mathrm{~km}^{3}\left(4,000 \mathrm{~km}^{3}+\right)$, but the deep recharge in $1.4 \mathrm{~km}^{3} / \mathrm{yr}$, indicating the occurrence of mining water in confined areas. The exploitable volumes were calculated in $2,014 \mathrm{~km}^{3}\left(+270 \mathrm{~km}^{3}\right)$, or $6 \%$ of SAG reserves, considering the maximum drawdown of water levels by pumping as $400 \mathrm{~m}$. If current exploitation was maintained at $1.04 \mathrm{~km}^{3} / \mathrm{yr}$, through the 1,800 wells that reach the $\mathrm{SAG}$ (a total of 8,000 known wells in the region), available reserves could be exploited by more than 2,000 years at current patterns of consumption" (Amore and Troger 2010, p. 2) 
2. There are already signs of stress on surface-water supplies. For example, Merin Lake, which is bordered by both Uruguay and Brazil, supplies water for much of Uruguay's rice production. Brazil withdraws significant amounts for irrigation as well; see Ministerio de Vivienda Ordenamiento Territorial y Medio Ambiente (2011). As a result, demands for water from the lake are stressing the regional ecosystem; the most likely candidate for an alternative source is the Guarani.

3. "In general, the main use of the waters of GAS is for public supply (66\%). The industrial use (refrigerators, sugar/alcohol plants, etc.) reaches $16 \%$, while in the countryside it is only $5 \%$. Recreational uses in thermal areas have reached $13 \%$ and $100 \%$ of water in Argentina is intended for tourist use. In Paraguay and Uruguay more than $90 \%$ of GAS water is used to supply urban areas" (Amore and Troger 2010, p. 3).

4. "Both in terms of population and groundwater production Brasil has a dominating role in the SAG [Guarani Aquifer System - Sistema Acuifero Guarani] region: $87 \%$ of the SAG population of 92 million inhabitants live on the Brasilian territory, and about $93 \%$ of the recent groundwater production (1,040 million $\mathrm{m}^{3}$ in 2007) happens in Brasil, mainly in the federal state of São Paulo" (Schmidt and Larroza 2010, p. 2). Besides the state of São Paulo, another seven Brazilian states overlie the Guarani Aquifer: Rio Grande do Sul, Santa Catarina, Paraná, Mato Grosso, Mato Grosso do Sul, Goiás and Minas Gerais.

5. Brazilian law construes equal access according to the principle of isonomy, which allows for differing capacities, needs and uses to dictate water-management and allocation policies.

6. See also Brazilian National Water Policy Management Act (1997, art. 1).

7. It is worth noting that the aforementioned objectives are aligned with the ones found in the 1997 Brazilian National Water Management Policy Act. See Brazilian National Water Management Policy Act (1997, No. 9.433).

\section{References}

Acordo sobre o Aquífero Guarani, 2010 [online]. Available from:http://internationalwaterlaw.org/ documents/regionaldocs/Guarani_Aquifer_Agreement-Portuguese.pdf [Accessed 19 July 2011].

Almanaque Brasil Socioambiental, 2008. In: B. Ricardo and M. Campanili, eds, Aqüifero Guarani. São Paulo: ISA, 177-194, 297.

Amore, L. and Tröger, U., 2010. Transboundary Guarani Aquifer System and groundwater management mechanisms. In: Proceedings of the ISARM2010 international conference "Transboundary aquifers: challenges and new directions", 6-8 December 2010. Available from: http://www.isarm.net/publications/325.

Beck, U., 1986. Risk society: towards a new modernity. London: Sage, 28-29.

Benjamin, A.H., Marques, C.L., and Tinker, C., 2005. The water giant awakes: an overview of water law in Brazil. Texas Law Review, 7 (83), 2218-2243.

Beto, R. and Campanili, M., 2008. Almanaque Brasil Socioambiental. Sao Paulo: ISA.

Brazilian Civil Code, 2002. Article 99. Available from: http://www.planalto.gov.br/ccivil_03/Leis/ 2002/L10406.htm. [Accessed 19 July 2011].

Brazilian National Water Management Policy Act, No. 9.433. 1997 [online]. Available from: http://www.cawater-info.net/bk/water_law/pdf/brazil2001.pdf [Accessed 6 March 2011].

Brzezinski, M., 2010. Regulating transboundary groundwater: big challenges for Brazil. In: Proceedings of the ISARM2010 international conference "Transboundary aquifers: challenges and new directions", 6-8 December 2010. Available from: http://www.isarm.net/ publications $/ 325$.

Constituição da República Federativa do Brasil, 1998. Presidency of the Republic Casa Civil Cabinet Subcommittee for Legal Affairs, 2010. Decree no 7,343 [online]. Available from: http://www.planalto.gov.br/ccivil_03/_Ato2007-2010/2010/Decreto/D7390.htm [Accessed 19 July 2011]

Eckstein, G., 2010. Hydraulic harmony or water whimsy? Guarani Aquifer countries sign agreement [online]. Available From: http://www.internationalwaterlaw.org/blog/?p=290 [Accessed 5 August 2010].

Freitas, V.P., 2002. Considerações Gerais. In: V.P. Freitas, ed. Águas: aspectos jurídicos e ambientais. Juruá: Curitiba, 17-18.

Hall, N.D., Stuntz, B.B., and Abrams R. H., 2008. Climate change and freshwater resources. WTR Natural Resources \& Environment, 22 (3), 34-35. 
IPCC, 2007. Climate change 2007: impacts, adaptation and vulnerability.

Krier, J.E., 1990. Risk and design. Journal of Legal Studies, 19 (2), 787.

Laffont, J.-J., 2000. Incentives and political economy. New York: Oxford University Press.

McAllister, L.K., 2008. Making law matter. Environmental protection \& legal institutions in Brazil. Stanford: Stanford Law Books.

McCaffrey, S.C. and McIntyre, O., 2010. Sovereignty and cooperative management of shared water resources in a time of shrinking availability: the role of internet international law; fragmentation in international water resources law. Reconciling the International Law Commission's 2008 Draft Articles on Transboundary Aquifers with the 1997 UN Watercourses Convention [CD-ROM].

Ministerio de Vivienda Ordenamiento Territorial y Medio Ambiente, 2011. Segunda comunicacioun nacional al conferencia de las partes en la convencion: marco de las nacional unidas sobre el cambio climatico. Unidad del Cambio Climatico, 226-227(2204) [online]. Available from: http://www.cambioclimatico.gub.uy//index.php?option=com_search\&Itemid= $5 \&$ searchword $=$ Segunda + comunicacion\&searchphrase=any\&ordering=newest $[$ Accessed 19 July 2011].

Pompeu, C.T., 2006. Direito de Águas no Brasil. São Paulo: RT, 41-45.

Posner, E.A. and Sunstein, C.R., 2008. Climate change justice. Georgetown Law Journal, 96, 1590.

Rowe, G. and Frewer, L.J., 2004. Evaluating public-participation exercises: a research agenda. Science, Technology \& Human Values, 29 (4), 520.

Sant'Anna, L.F.H., 2002. General overview of Brazilian environmental law 2002. SPG International Law Practicum, 15, 22.

Schelling, T.C., 1992. Some economics of global warming. American Economic Review, 82 (1).

Schmidt, G. and Larroza, F., 2010. Pedro Juan Caballero - Ponta Porã. A groundwater transboundary situation between Paraguay and Brasil, 1. In: Proceedings of the ISARM2010 international conference "Transboundary aquifers challenges and new directions", 6-8 December 2010. Available from: http://www.isarm.net/publications/325.

Schroeder, C.H., 1986. Rights against risks. Columbia Law Review, 86 (3), 497.

Sunstein, C.R., 2004. Cost-benefit analysis and the environment. University of Chicago, Olin Law \& Economics Program. Working paper 227.

UNGA, 2008. UN General Assembly Resolution on the Law of Transboundary Aquifers. A/RES/63/124. Available from: http://internationalwaterlaw.org/documents/intldocs/ UNGA_Resolution_on_Law_of_Transboundary_Aquifers.pdf [Accessed 29 July 2011].

Usunoff, E., n.d. Web based information for integrated water resources management of a multi-national aquifer: the global environment facility project on the Guarari Aquifer [online]. Instituto de Hidrología de Llanuras. Available from: http://www.waterweb.org/ wis3/presentations/30_Usunoff_paper.pdf [Accessed 19 July 2011].

Wildavsky, A., 1966. The political economy of efficiency: cost-benefit analysis, systems analysis, and program budgeting. Public Administration Review, 26 (4), 296.

World Bank, 2009. Implementation completion and results report (Project ID: Po68121 L/C/TF Number(s): TF-50950 TF-51223. Report No.: ICR00001198. Environmental Protection and Sustainable Development of the Guarani Aquifer System Project [online]. Available from: Http://www-wds.worldbank.org/external/default/WDSContentServer/WDSP/IB/2009/08/13/ 000333037_20090813231853/Rendered/PDF/ICR11980P068121IC0disclosed08112191.pdf [Accessed 19 July 2011]. 